\title{
Synthesis and Structural Characterization of Lithium and Trimethyltin Complexes of 2,6-Bis(oxazolinyl)phenyl
}

\author{
Marianne Stol, ${ }^{\dagger}$, Dennis J. M. Snelders,${ }^{\dagger}$ Jeroen J. M. de Pater ${ }^{\dagger}$ \\ Gerard P. M. van Klink, ${ }^{\dagger}$ Huub Kooijman, ${ }^{\S}$ Anthony L. Spek, ${ }^{\S, \|}$ and \\ Gerard van Koten*,†
}

\begin{abstract}
Dutch Polymer Institute and Debye Institute, Department of Metal-Mediated Synthesis, and Bijvoet Center for Biomolecular Research, Department of Crystal and Structural Chemistry, Utrecht University, Padualaan 8, 3584 CH Utrecht, The Netherlands
\end{abstract}

Received September 21, 2004

The treatment of 2,6-bis(oxazolinyl)phenyl bromide (Phebox-Br) with $n$-BuLi affords a Phebox-Li complex. Subsequent transmetalation with [SnClMe 3 ] affords a Phebox-Sn complex. The Phebox ligand can coordinate to a transition metal in various terdentate fashions; both the oxazoline oxygen and the imine nitrogen are perfectly positioned for chelation; "NCN", "OCO", or mixed terdentate coordination modes are theoretically possible using this ligand. The structural properties and NMR spectra of $\left[\mathrm{Sn}(\mathrm{Me}, \mathrm{Me}-\mathrm{Phebox}) \mathrm{Me}_{3}\right]$ (2) and $\left[\mathrm{Li}\left(\mathrm{R}, \mathrm{R}^{\prime}\right.\right.$-Phebox $\left.)\right]$ complexes $3 \mathbf{a}\left(\mathrm{R}=\mathrm{R}^{\prime}=\mathrm{Me}\right), \mathbf{3 b}\left(\mathrm{R}=i \operatorname{Pr}, \mathrm{R}^{\prime}=\mathrm{H}\right)$, and $\mathbf{3 c}(\mathrm{R}=$ $t \mathrm{Bu}, \mathrm{R}^{\prime}=\mathrm{H}$ ) were investigated. It was found that 2 exhibits no chelation of the Phebox ligand to the $\mathrm{Sn}$ center in this case. The [Li(R,R'-Phebox $)]$ complex $3 \mathbf{a}$ has been crystallographically characterized and is in the form of a molecular dimer (i.e. $[\mathrm{Li}(\mathrm{Phebox})]_{2}$ ), containing two formally three-center-two-electron bonds in a four-membered $\mathrm{Li}_{2} \mathrm{C}_{2}$ ring. The formal Phebox anion is bonded to the lithium cation via the two ortho imine $\mathrm{N}$ centers and the intraannular aromatic $\mathrm{C}$ atom. The ${ }^{13} \mathrm{C}\left\{{ }^{1} \mathrm{H}\right\}$ NMR signal of $\mathrm{C}_{\text {ipso }}$, being a seven-line

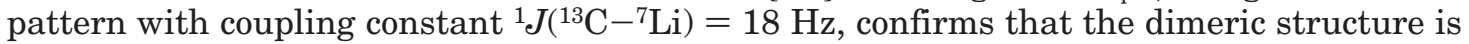
maintained in solution at room temperature. Variable-temperature (VT) NMR studies of 3a indicate that a fluxional process is occurring at room temperature, which can be frozen out below $-16{ }^{\circ} \mathrm{C}\left(\Delta G^{\ddagger}=56 \mathrm{~kJ} / \mathrm{mol}\right)$. This fluxional process is not observed in VT-NMR studies on 3b,c. This is likely due to the presence of bulky ( $i \operatorname{Pr}$ or $t \mathrm{Bu})$ substituents that effectively shut down the pathways to rapid inversion of the puckering of the five-membered chelate ring.

\section{Introduction}

Chelating aryl ligands are an important class of ligands in homogeneous catalysis ${ }^{1}$ and also in other fields of interest. ${ }^{1 b, 2}$ One of the classes of chelating ligands which is applied in homogeneous catalysis is the monoanionic bis(oxazolinyl)phenyl or Phebox ligand. An interesting feature of Phebox ligands is the ease of synthesis of a number of chiral analogues. Phebox ligands have been previously shown to coordinate in a terdentate fashion; ${ }^{3}$ both the oxazoline oxygen and nitrogen can potentially be positioned for chelation, and hence, "NCN", "OCO", or mixed "NCO" terdentate coordination modes are theoretically possible using this

* To whom correspondence should be addressed. Tel: +3130 2533120. Fax: +3130 2523615. E-mail: g.vankoten@chem.uu.nl.

Debye Institute.

$¥$ Dutch Polymer Institute

$\S$ Bijvoet Center for Biomolecular Research.

"Address correspondence pertaining to crystallographic studies to this author. E-mail: A.L.Spek@chem.uu.nl.

(1) For leading references see: (a) Singleton, J. T. Tetrahedron 2003 59, 1837-1857. (b) Albrecht, M.; van Koten, G. Angew. Chem., Int. Ed. 2001, 40, 3750-3781. (c) van der Boom, M. E.; Milstein, D. Chem. Rev. 2003, 103, 1759-1792.

(2) (a) Albrecht, M.; Rodríguez, G.; Schoenmaker, J.; van Koten, G. Org. Lett. 2000, 2, 3461-3464. (b) Guillena, G.; Kruithof, C. A.; Casado, M. A.; Egmond, M. R.; van Koten, G. J. Organomet. Chem. 2003, 668, $3-7$ class of metal binding agents. In the terdentate bonding mode, Phebox ligands have three $\mathrm{C}$, and $\mathrm{O}$ - or $\mathrm{N}$-donor sites in fixed positions. This is due to the fact that the ortho-chelating ligands are connected to the aryl ring by an $\mathrm{sp}^{2} \mathrm{C}$ and one $\mathrm{sp}^{2} \mathrm{~N}$ or $\mathrm{sp}^{3} \mathrm{O}$ center. For this reason, the binding is predicted to be less flexible in comparison to the wide variety of bonding modes encountered in the aryldiamine ligands, the so-called "NCN-pincer" ligands. ${ }^{1 b, 4}$ We were interested in the structural properties, both in the solid state and in solution, and the mode of coordination $(\mathrm{C}, \mathrm{N}-$ vs $\mathrm{C}, \mathrm{O}-$ chelation) of the Phebox ligand in simple model complexes incorporating $\mathrm{Li}$ or $\mathrm{Sn}$ metal. ${ }^{3 \mathrm{e}}$ In a triorganotin

(3) (a) Motoyama, Y.; Makihara, N.; Mikami, Y.; Aoki, K.; Nishiyama, H. Chem. Lett. 1997, 951-952. (b) Denmark, S. E.; Stavenger, R. A.; Faucher, A. -M.; Edwards, J. P. J. Org. Chem. 1997, 62, 33753389. (c) Motoyama, Y.; Mikami, Y.; Kawakami, H.; Aoki, K.; Nishiyama, H. Organometallics 1999, 18, 3584-3588. (d) Stark, M. A.; Jones, G.; Richards, C. J. Organometallics 2000, 19, 1282-1291. (e) Motoyama, Y.; Okano, M.; Narusawa, H.; Makihara, N.; Aoki, K.; Nishiyama, H. Organometallics 2001, 20, 1580-1591. (f) Motoyama, Y.; Shimozono, K.; Aoki, K.; Nishiyama, H. Organometallics 2002, 21, 1684-1696. (g) Motoyama, Y.; Kawakami, H.; Shimozono, K.; Aoki, K.; Nishiyama, H. Organometallics 2002, 21, 3408-3416. (h) Motoyama, Y.; Koga, Y.; Kobayashi, K.; Aoki, K.; Nishiyama, H. Chem. Eur. J. 2002, 8, 2968-2975. (i) Fossey, J. S.; Richards, C. J. Organometallics 2004, 23, 367-373.

(4) Rietveld, M. H. P.; Grove, D. M.; van Koten, G. New J. Chem. 1997, 21, 751-771. 


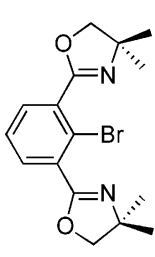

1a

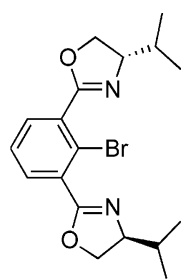

$1 \mathrm{~b}$

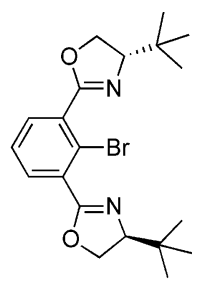

$1 c$
Figure 1. Achiral and chiral Phebox-Br ligands.

Phebox complex, the Phebox fragment will be attached to the $\mathrm{Sn}$ nucleus via a direct aryl $\mathrm{C}-\mathrm{Sn}$ bond. The question then arises as to how the ortho substituents orient themselves relative to the electrophilic Sn center. In an isolated Phebox-Li compound, a dimeric structure is anticipated, ${ }^{5}$ although steric constraints could give rise to novel or unusual structural features.

\section{Results and Discussion}

Three different Phebox ligands were synthesized in this work. One achiral Phebox ligand (1a) was derived from 2-amino-2-methyl-1-propanol, and two chiral Phebox ligands (1b,c, respectively; Figure 1) were obtained from L-valinol and L-tert-leucinol.

2,6-Bis $\left(4^{\prime}, 4^{\prime}\right.$-dimethyl-2'-oxazolinyl)phenyl bromide ([Me,Me-PheboxBr], 1a), was synthesized using modified literature procedures. ${ }^{3 e, 6}$ Compound 1a can be lithiated, via selective $\mathrm{Li}-\mathrm{Br}$ exchange, with $n$-BuLi in THF solution. ${ }^{3 e}$ After the product was treated with [SnClMe $]$, [Sn(Me,Me-Phebox $) \mathrm{Me}_{3}$ ] (2) was obtained. ${ }^{3 e}$ To study a possible solvent dependence of this reaction, $[\mathrm{Me}, \mathrm{Me}-\mathrm{PheboxBr}]$ was reacted with $n$-BuLi in both polar coordinating solvents (THF and diethyl ether) and apolar solvents (pentane and toluene) (Scheme 1). The reaction mixture was quenched with $\left[\mathrm{SnClMe}_{3}\right]^{3 \mathrm{e}}$ and the conversion studied by ${ }^{1} \mathrm{H}$ NMR spectroscopy.

In all cases, selective $\mathrm{Li}-\mathrm{Br}$ exchange occurred and quantitative formation of $\mathbf{2}$ was observed. Thus, suppression of the directed ortho metalation of $\mathbf{1 a}$ (i.e. metalation at the aryl C-3 position) is accomplished by these synthetic protocols. ${ }^{7}$

The ${ }^{1} \mathrm{H}$ NMR spectrum of a solution of $2\left(\mathrm{C}_{6} \mathrm{D}_{6}\right.$, room temperature) reveals singlet resonances for both the oxazoline methyl groups and ring methylene protons $(\delta$ 1.17 and $3.70 \mathrm{ppm}$, respectively). The $\mathrm{Sn}-\mathrm{Me}$ groups are centered at $\delta 0.46 \mathrm{ppm}$, with the diagnostic ${ }^{117} \mathrm{Sn} /$ ${ }^{119} \mathrm{Sn}$ satellites $\left({ }^{2} J_{\mathrm{H}-\mathrm{Sn}}=26.7,27.8 \mathrm{~Hz}\right)$ confirming the presence of the $\mathrm{SnMe}_{3}$ group. It is known that the magnitude of ${ }^{1} \mathrm{H}-\mathrm{Sn}$ spin-spin coupling constants are a function of the coordination number in tin(IV) com-

(5) (a) Smeets, W. J. J.; Spek, A. L. Acta Crystallogr. 1987, C43, 1429-1430. (b) van der Zeijden, A. A. H.; van Koten, G. Recl. Trav. Chim. Pays-Bas 1988, 107, 431-433. (c) Donkervoort, J. G.; Vicario, J. L.; Rijnberg, E.; Jastrzebski, J. T. B. H.; Kooijman, H.; Spek, A. L.; van Koten, G. J. Organomet. Chem. 1998, 550, 463-467. (d) Steenwinkel, P.; James, S. L.; Grove, D. M.; Veldman, N.; Spek, A. L.; van Koten, G. Chem. Eur. J. 1996, 2, 1440-1445. (e) Schlengerman, R.; Sieler, J.; Jelonek, S.; Hey-Hawkins, E. Chem. Commun. 1997, 197198. (f) Stey, T.; Stalke, D. In The Chemistry of Organolithium Compounds; Rappoport, Z., Marek, I., Eds.; Wiley: London, 2004. (g) Gossage, R. A.; Jastrzebski, J. T. B. H.; van Koten, G. Angew. Chem., Int. Ed., in press.

(6) (a) Rodríguez, G.; Albrecht, M.; Schoenmaker, J.; Ford, A.; Lutz, M.; Spek, A. L.; van Koten, G. J. Am. Chem. Soc. 2002, 124, 51275138. (b) Vorbrüggen, H.; Krolikiewicz, K. Tetrahedron 1993, 49, 93539372.

(7) Steenwinkel, P.; Gossage, R. A.; van Koten, G. Chem. Eur. J. 1998, 4, 759-762.
Scheme 1. Synthesis of [Sn(Me,Me-Phebox $\left.) \mathrm{Me}_{3}\right]$ in Apolar and Polar Solvents
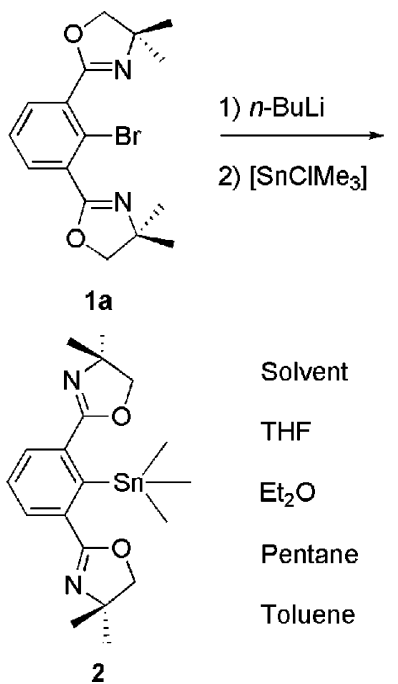

Solvent
THF
$\mathrm{Et}_{2} \mathrm{O}$
Pentane
Toluene

Temp. $\left({ }^{\circ} \mathrm{C}\right) \quad$ Time $(\mathrm{h})$

Conversion

$-78$

0.17

quant.

quant.

quant.

quant.

pounds. ${ }^{8}$ The observed ${ }^{2} J_{\mathrm{H}-\mathrm{Sn}}$ values indicate that the tin center in $\mathbf{2}$ is tetracoordinated ${ }^{9}$ (i.e. with no significant $\mathrm{Sn}-\mathrm{O}$ or $\mathrm{Sn}-\mathrm{N}$ coordination). This conclusion is further corroborated by the molecular structure of $\mathbf{2}$ in the solid state. Single crystals of $\mathbf{2}$ were obtained by slow evaporation of a pentane solution of the complex at room temperature. A view of the molecular structure is shown in Figure 2.

The molecule has an approximate local plane of symmetry containing $\mathrm{C}(4), \mathrm{C}(1), \mathrm{Sn}$, and $\mathrm{C}(18)$ (the torsion angle $\mathrm{C}(18)-\mathrm{Sn}-\mathrm{C}(1)-\mathrm{C}(6)$ is $\left.99.63(17)^{\circ}\right)(\mathrm{RMS}$ deviation of ideal positions $\pm 0.08 \AA$ ). The configuration at tin can be described as a distorted tetrahedron, as is shown by the bond angles around tin, where the angle $\mathrm{C}(1)-\mathrm{Sn}-\mathrm{C}(18)$ is opened to $113.6^{\circ}$ and the angle $\mathrm{C}(17)-\mathrm{Sn}-\mathrm{C}(19)$ is compressed to $103.70(8)^{\circ}$. The $\mathrm{Sn}-$ $\mathrm{Me}$ and $\mathrm{Sn}-\mathrm{Ar}$ bond lengths correspond well with bond lengths reported in the literature (2.08-2.19 and 2.15$2.18 \AA$ ) for similar tin compounds. ${ }^{10}$ The oxazoline substituents are rotated with respect to the plane defined by the aryl ring by $27.19(10)^{\circ}$ (substituent containing $\mathrm{O}(1)$ ) and $22.81(10)^{\circ}$ (substituent containing $\mathrm{O}(2)$ ). The absence of additional coordination of the Sn center by the oxazoline moieties is further indicated by the position of the Sn center out of the plane of the aryl ring. The angle $\mathrm{C}(4)-\mathrm{C}(1)-\mathrm{Sn}$ is $164.68(10)^{\circ}$ (i.e. the Sn center is "lifted" by $\sim 0.612(1) \AA$ out of the leastsquares aryl plane). These structural features point to steric interaction between the $\mathrm{SnMe}_{3}$ group and the oxazoline ring substituents. There is no evidence of the oxazoline $\mathrm{N}$ or $\mathrm{O}$ atoms interacting with the $\mathrm{Sn}$ center, although this is a feature in other tetravalent $\mathrm{Sn}$ compounds. ${ }^{10 \mathrm{a}, \mathrm{d}}$ The distances between the oxazoline oxygens and the Sn center are 2.9842(13) and 3.0271(14) $\AA$, respectively. These lengths are distinctively

(8) Jastrzebski, J. T. B. H.; van Koten, G. Adv. Organomet. Chem 1993, 35, 257.

(9) ${ }^{2} J_{\mathrm{H}-\mathrm{Sn}}$ is 26.2 and $27.5 \mathrm{~Hz}$ for $\left[\mathrm{SnPhMe}_{3}\right]$.

(10) (a) Davenport, A. J.; Davies, D. L.; Fawcett, J.; Russel, D. R. Dalton 2002, 3260-3264. (b) Schulte, M.; Gabbai, F. P. Chem. Eur. J. 2002, 8, 3802-3806. (c) Schilling, B.; Kaiser, V.; Kaufmann, D. E. Chem. Ber. 1997, 130, 923-932. (d) Steenwinkel, P.; Jastrzebski, J. T. B. H.; Deelman, B.-J.; Grove, D. M.; Kooijman, H.; Veldman, N.; Smeets, W. J. J.; Spek, A. L.; van Koten, G. Organometallics 1997, $16,5486-5498$. 


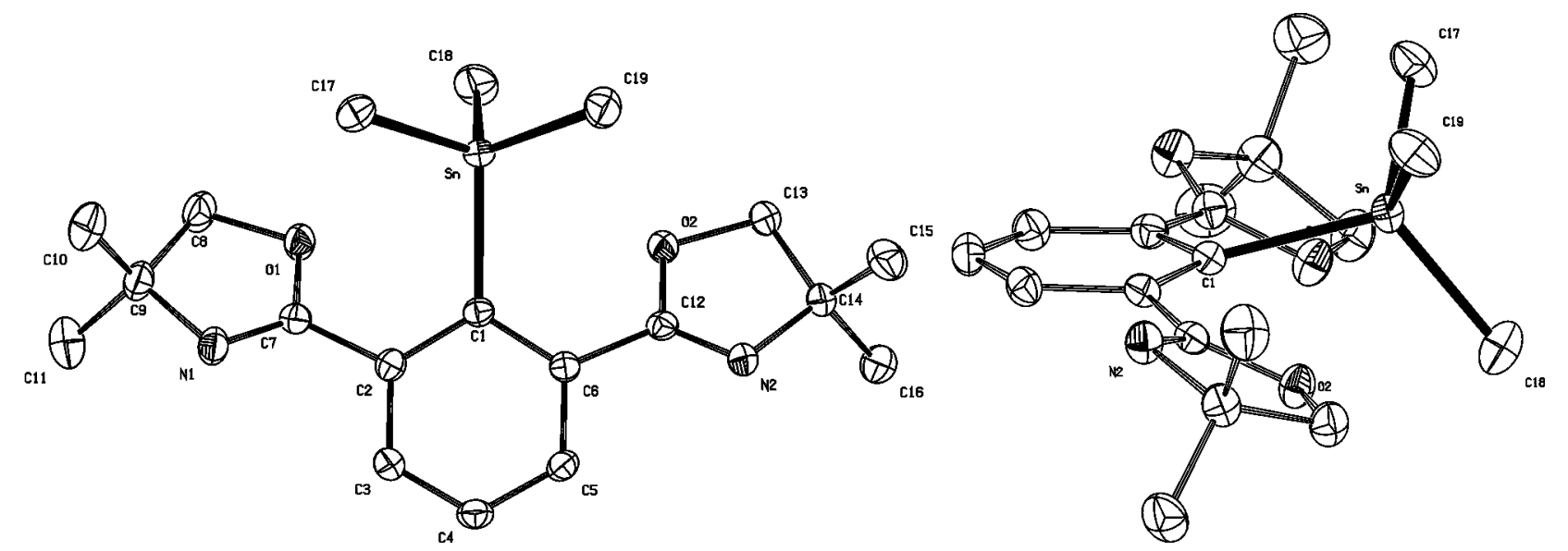

Figure 2. Top and side-on views of the crystal structure of [Sn(Me,Me-Phebox $) \mathrm{Me}_{3}$ ]. Hydrogen atoms have been omitted for clarity. Relevant bond distances $(\AA)$ and angles $(\mathrm{deg})$ : $\mathrm{Sn}-\mathrm{C}(1)=2.1810(18), \mathrm{Sn}-\mathrm{C}(17)=2.150(2), \mathrm{Sn}-\mathrm{C}(18)=2.129$ $(3), \mathrm{Sn}-\mathrm{C}(19)=2.153(2), \mathrm{Sn}-\mathrm{O}(1)=2.9842(13), \mathrm{Sn}-\mathrm{O}(2)=3.0271(14) ; \mathrm{C}(1)-\mathrm{Sn}-\mathrm{C}(17)=106.03(8), \mathrm{C}(1)-\mathrm{Sn}-\mathrm{C}(18)=$ $113.64(8), \mathrm{C}(1)-\mathrm{Sn}-\mathrm{C}(19)=108.45(7), \mathrm{C}(17)-\mathrm{Sn}-\mathrm{C}(18)=112.18(9), \mathrm{C}(17)-\mathrm{Sn}-\mathrm{C}(19)=103.70(8), \mathrm{C}(18)-\mathrm{Sn}-\mathrm{C}(19)=$ 112.18(9).

\section{Scheme 2. Synthesis of [Li(R,R'-Phebox $)]$ Complexes}
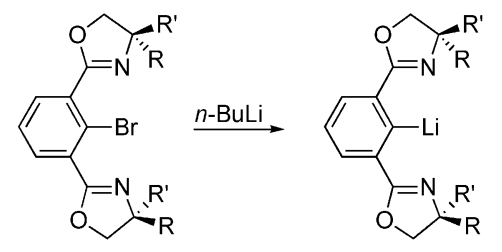

1a $R=R^{\prime}=M e$
1b $R=i P r, R^{\prime}=H$
1c $R=t B u, R^{\prime}=H$

$3 a \mathrm{R}=\mathrm{R}^{\prime}=\mathrm{Me}(66 \%)$

3b $\mathrm{R}=i \mathrm{Pr}, \mathrm{R}^{\prime}=\mathrm{H}$ (quant.)

$3 c R=t B u, R^{\prime}=H(42 \%)$

longer than corresponding $\mathrm{Sn}-\mathrm{O}$ distances reported previously for tetraorganotin compounds, where weak Sn-O interactions $(2.770,2.781 \AA)^{11}$ are inferred. The oxazoline $\mathrm{N}$ is most likely too sterically hindered to approach the tin center, by virtue of the adjacent $\mathrm{Me}$ groups in the ring, while the oxazoline $\mathrm{O}$ donor site is probably too weak a donor for coordination.

For the structural characterization of $\left[\mathrm{Li}\left(\mathrm{R}, \mathrm{R}^{\prime}-\mathrm{Phe}\right.\right.$ box $)]_{2}$ complexes, 3a $\left(\mathrm{R}=\mathrm{R}^{\prime}=\mathrm{Me}\right), \mathbf{3 b}\left(\mathrm{R}=i \mathrm{Pr}, \mathrm{R}^{\prime}=\right.$ $\mathrm{H})$, and 3c $\left(\mathrm{R}=t \mathrm{Bu}, \mathrm{R}^{\prime}=\mathrm{H}\right)$ were synthesized and isolated (Scheme 2).

To address the structural motif(s) of these organolithium species, single crystals were obtained from a saturated solution of $\mathbf{3 a}\left(\mathrm{Et}_{2} \mathrm{O},-30{ }^{\circ} \mathrm{C}\right)$. The molecular structure, depicted in Figure 3, confirms the anticipated dimeric form and shows distinct NCN chelation (cf. 2) of the Phebox ligand.

Both aryl groups bridge the two lithium atoms via a three-center-two-electron $\mathrm{C}_{\mathrm{ipso}} \mathrm{Li}_{2}$ bonding interaction. Both lithium atoms have distorted-tetrahedral geometries, and the two Phebox ligands are almost perpendicular to each other (angle beween the least-squares planes through the ring atoms is $84.67(7)^{\circ}$ ) with the two $\mathrm{Li}$ atoms above and below the plane of the aryl rings. This type of structure can be in the form of three different modes of chelation (Figure 4) with two different donor atoms $(\mathrm{O}, \mathrm{N})$.

(11) (a) Willemsen, L. C.; van der Kerk, G. J. M. Investigations in the Field of Organolead Chemistry; International Lead Zinc Research Organisation: Utrecht, The Netherlands, 1965. (b) Nefedov, O. M.; Kolesnikov, S. P.; Ioffe, A. I. J. Organomet. Chem. Libr. 1981, 5, 181.
From the crystal structure data, it is clear that [Me,Me-PheboxLi $]_{2}(\mathbf{3 a})$ is present as aggregate type $\mathbf{A}$ in the solid state. In the related compound $\left[\left(\mathrm{Et}_{2} \mathrm{O}\right) \mathrm{LiC}_{6} \mathrm{H}_{4} \mathrm{C}\right.$ (O) $\left.\mathrm{N}(i \mathrm{Pr})_{2}\right]_{2},{ }^{12} \mathrm{C}=\mathrm{O}$ donation is preferred over $i \operatorname{Pr}_{2} \mathrm{~N}$ donation. In our case, imine $\mathrm{N}$ coordination is preferred over $\mathrm{O}$ donation, which is, to our knowledge, the first crystallographically characterized organolithium compound with intramolecular $\mathrm{C}=\mathrm{N}$ chelates present in the structure. ${ }^{13}$ Synthetically, it also appears that $\mathrm{Li}-\mathrm{Br}$ exchange is favored over $n$-BuLi addition to the $\mathrm{C}=\mathrm{N}$ double bond. ${ }^{14}$ In addition, the product ArLi species are obviously also unreactive toward the imine functionalities. The $\mathrm{C}_{\text {ipso }}-\mathrm{Li}$ bond lengths $(2.25-2.30 \AA)$ are slightly longer than in comparable structures with two donating amine arms $(2.19-2.24 \AA) .5$ The opposite trend is observed for the $\mathrm{Li}-\mathrm{N}$ bond lengths. These are somewhat shorter $(1.99-2.01 \AA)$ than distances found in the literature for amine donor systems (2.07-2.13 $\AA$ ). ${ }^{5}$ The $\mathrm{Li} \cdot \cdot \mathrm{Li}$ distance $(2.333(4) \AA)$ is also shorter than in the bis(amino)aryl systems $(2.40-2.48 \AA) .^{5}$ The angles between the nonplanar $\mathrm{C}_{2} \mathrm{Li}_{2}$ rhombus and the aryl planes $\left(42.39(11)\right.$ and $\left.42.74(11)^{\circ}\right)$ are smaller than found in other NCN chelating systems $\left(56-59^{\circ}\right) .{ }^{5}$ Elongation of the $\mathrm{C}_{\mathrm{ipso}}-\mathrm{Li}$ bond distances and shortening of the $\mathrm{Li}-\mathrm{N}$ and $\mathrm{Li} \cdot \cdot \mathrm{Li}$ distances may be the result of a stronger interaction of the $\mathrm{Li}$ centers with the imine groups as opposed to the interaction with tertiary amines. The acute angle $\mathrm{Li}-\mathrm{C}_{\mathrm{ipso}}-\mathrm{Li}\left(62^{\circ}\right)$ is smaller than comparable literature values $\left(66-68^{\circ}\right),{ }^{5}$ as a result of reduced repulsion between the $\mathrm{Li}$ atoms.

The ${ }^{1} \mathrm{H}$ and ${ }^{13} \mathrm{C}\left\{{ }^{1} \mathrm{H}\right\}$ NMR spectra (room temperature) of $\mathbf{3 a}-\mathbf{c}$ suggest that all three $\left[\mathrm{Li}\left(\mathrm{R}, \mathrm{R}^{\prime}-\mathrm{Phebox}\right)\right]_{n}$ complexes have distinct dimeric structures in solution. The ${ }^{13} \mathrm{C}\left\{{ }^{1} \mathrm{H}\right\}$ NMR signal for $\mathrm{C}_{\text {ipso }}$ is observed as a sevenline pattern (intensities 1:2:3:4:3:2:1) and a coupling constant ${ }^{1} J\left({ }^{13} \mathrm{C}-{ }^{7} \mathrm{Li}\right)$ of $18 \mathrm{~Hz}$. This pattern, as well as the magnitude of ${ }^{1} J_{\mathrm{C}-\mathrm{Li}}$, is direct proof that $\mathrm{C}_{\text {ipso }}$ is bonded to two Li atoms. The above coupling constant is similar to the value found for dimeric $\left[\mathrm{Li}\left(\mathrm{C}_{6} \mathrm{H}_{3}\left(\mathrm{CH}_{2^{-}}\right.\right.\right.$

(12) Clayden, J.; Davies, R. P.; Hendy, M. A.; Snaith, R.; Wheatley, A. E. H. Angew. Chem., Int. Ed. 2001, 40, 1238-1240.

(13) We are aware of the compound $\left[\left(\mathrm{Et}_{2} \mathrm{O}\right)\left\{\mathrm{LiC}_{6} \mathrm{H}_{4} \mathrm{P}(\mathrm{Ph})_{2} \mathrm{NSiMe}_{3}\right\}_{2}\right]$, which has a $\mathrm{P}=\mathrm{N}$ bond present: Steiner, A.; Stalke, D. Angew. Chem., Int. Ed. Engl. 1995, 34, 1752.

(14) Nückel, S.; Burger, P. Organometallics 2000, 19, 3305-3311. 

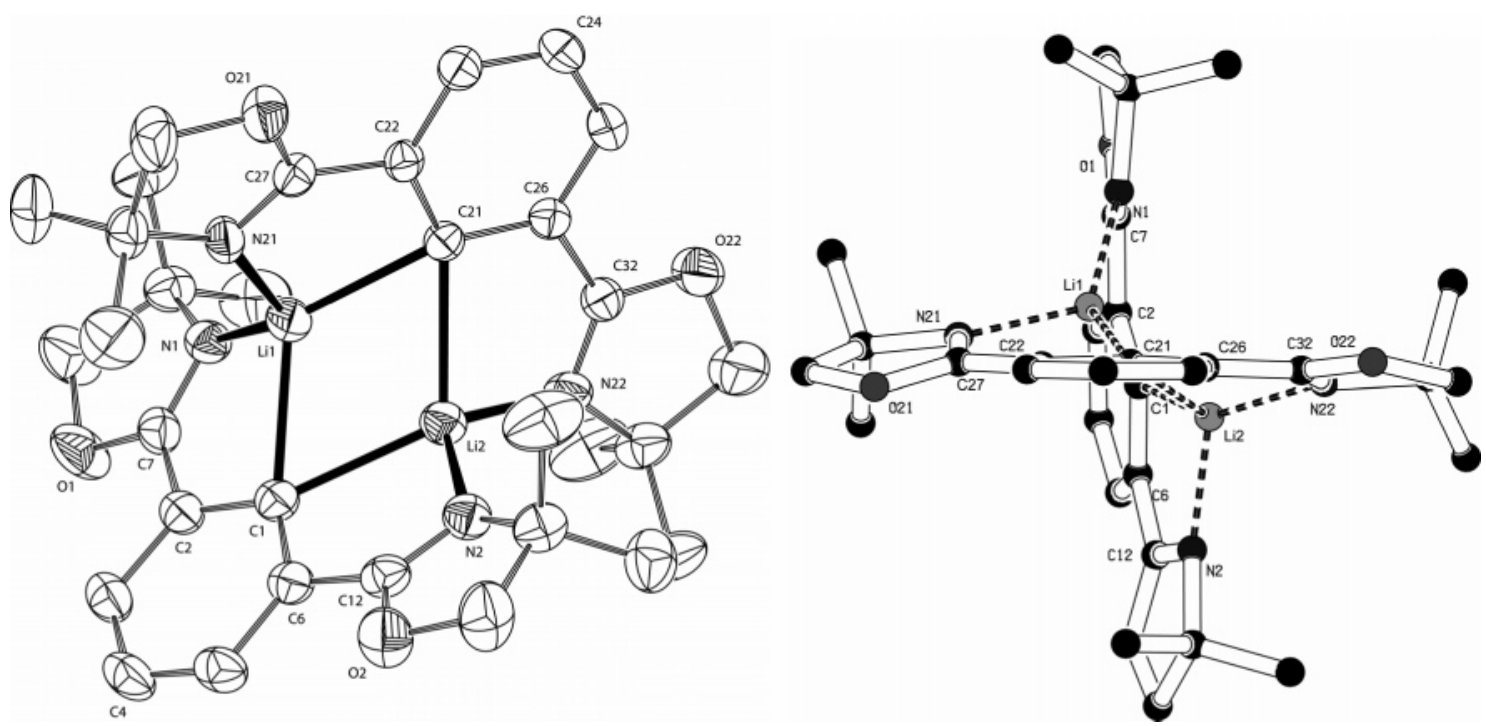

Figure 3. Top and side-on views of the crystal structure of $[\mathrm{Li}(\mathrm{Me}, \mathrm{Me}-\mathrm{Phebox})]_{2}$. Hydrogen atoms have been omitted for clarity. Relevant bond distances $(\AA)$ and angles $(\mathrm{deg}): \mathrm{C}(1)-\mathrm{Li}(1)=2.268(3), \mathrm{C}(1)-\mathrm{Li}(2)=2.289(3), \mathrm{C}(21)-\mathrm{Li}(1)=2.247$ (3), $\mathrm{C}(21)-\mathrm{Li}(2)=2.299(3), \mathrm{Li}(1)-\mathrm{N}(1)=2.004(3), \mathrm{Li}(1)-\mathrm{N}(21)=1.987(3), \mathrm{Li}(2)-\mathrm{N}(2)=1.989(3), \mathrm{Li}(2)-\mathrm{N}(22)=2.006(3)$; $\mathrm{Li}(1)-\mathrm{C}(1)-\mathrm{Li}(2)=61.61(10), \mathrm{Li}(1)-\mathrm{C}(21)-\mathrm{Li}(2)=61.74(10), \mathrm{C}(1)-\mathrm{Li}(1)-\mathrm{C}(21)=117.99(13), \mathrm{C}(1)-\mathrm{Li}(1)-\mathrm{N}(1)=84.46-$ $(10), \mathrm{C}(1)-\mathrm{Li}(1)-\mathrm{N}(21)=114.11(14), \mathrm{N}(1)-\mathrm{Li}(1)-\mathrm{N}(21)=121.39(14), \mathrm{N}(21)-\mathrm{Li}(1)-\mathrm{C}(21)=85.76(11), \mathrm{N}(1)-\mathrm{Li}(1)-\mathrm{C}(21)$ $=135.61(15), \mathrm{C}(1)-\mathrm{Li}(2)-\mathrm{C}(21)=115.03(12), \mathrm{C}(1)-\mathrm{Li}(2)-\mathrm{N}(2)=84.78(11), \mathrm{C}(1)-\mathrm{Li}(2)-\mathrm{N}(22)=139.79(14), \mathrm{N}(2)-\mathrm{Li}(2)-$ $\mathrm{N}(22)=118.46(14), \mathrm{N}(22)-\mathrm{Li}(2)-\mathrm{C}(21)=84.24(11), \mathrm{N}(2)-\mathrm{Li}(2)-\mathrm{C}(21)=117.84(13)$.
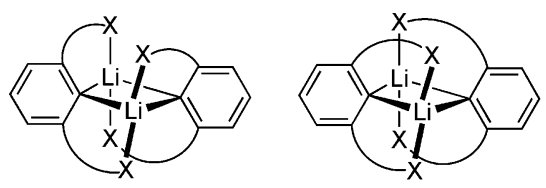

B

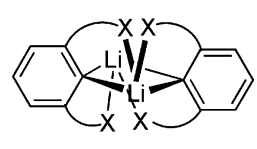

C

Figure 4. Possible modes of chelation.

$\left.\left.\left.\mathrm{NMe}_{2}\right)_{2}-2,6\right)\right]_{2}(20.5 \mathrm{~Hz}) .{ }^{15}$ Moreover, these features are temperature independent, indicating that the dimeric structure is apparently preserved over the temperature range -60 to $25{ }^{\circ} \mathrm{C}$. Hence, the three-center-twoelectron $\mathrm{C}-\mathrm{Li}$ bonding motif (cf. X-ray data of 3a) is also retained in solution.

The remaining resonances in the ${ }^{1} \mathrm{H}$ and ${ }^{13} \mathrm{C}\left\{{ }^{1} \mathrm{H}\right\}$ NMR spectra of $\mathbf{3 a}$ (toluene- $d_{8}$ ), however, exhibit temperature dependence. At $25{ }^{\circ} \mathrm{C}$, the methylene protons and methyl protons appear as singlets in the ${ }^{1} \mathrm{H}$ NMR spectrum; the ${ }^{13} \mathrm{C}\left\{{ }^{1} \mathrm{H}\right\}$ NMR spectrum also has two singlet signals for the methylene carbon and methyl substituents, respectively. At $-50{ }^{\circ} \mathrm{C}$, the $\mathrm{CH}_{2}$ grouping now appears $\left({ }^{1} \mathrm{H} \mathrm{NMR}\right)$ as an $\mathrm{AB}$ pattern $\left(\delta_{\mathrm{A}} 3.55 \mathrm{ppm}\right.$, $\delta_{\mathrm{B}} 3.58 \mathrm{ppm}, J_{\mathrm{AB}}=8.6 \mathrm{~Hz}$ ) and the $\mathrm{CMe}_{2}$ groups are separated into two singlets (at 0.73 and $0.83 \mathrm{ppm}$, respectively). This aspect is also apparent in the ${ }^{13} \mathrm{C}$ $\left\{{ }^{1} \mathrm{H}\right\}$ NMR spectrum $\left(-60^{\circ} \mathrm{C}\right)$, where two signals at 28.3 and $28.2 \mathrm{ppm}$ are found for the $\mathrm{CMe}_{2}$ groups.

The described observations can be explained by considering the ring puckering present in the four fivemembered chelate rings, as demonstrated by the structure in the solid state. The ring puckering of the four chelate rings is coupled, and all have either the $\Lambda$ or the $\Delta$ configuration. As a result, $\mathbf{3 a}$ exists in the slowexchange limit as a 1:1 mixture of two enantiomers. In the fast-exchange limit rapid inversion of the ring

(15) Jastrzebski, J. T. B. H.; van Koten, G.; Konijn, M.; Stam, C. H. J. Am. Chem. Soc. 1982, 104, 5490-5492.

puckering by rotation (wagging) about the $\mathrm{C}(4)-\mathrm{C}_{\mathrm{ipso}}-$ $\mathrm{C}^{\prime}{ }_{\mathrm{ipso}}-\mathrm{C}(24)$ axis provides $3 \mathbf{a}$ with an apparent molecular symmetry plane containing the methylene and the $\mathrm{C}\left(\mathrm{Me}_{2}\right)$ carbon centers. Consequently, this inversion process renders the $\mathrm{CH}_{2}$ protons and $\mathrm{CMe}_{2}$ methyl groupings enantiotopic. This view is corroborated by the observation that the $\mathrm{CH}_{2}$ resonances coalesce $\left({ }^{1} \mathrm{H}\right.$ NMR $)$ at $-16{ }^{\circ} \mathrm{C}$, which corresponds to $\Delta G^{\ddagger}=57 \mathrm{~kJ} / \mathrm{mol},{ }^{16}$ while the related $\mathrm{CMe}_{2}$ resonances coalesce at $-14{ }^{\circ} \mathrm{C}$ and hence a $\Delta G^{\ddagger}$ value of $55 \mathrm{~kJ} / \mathrm{mol}$ is calculated. ${ }^{16}$ The ${ }^{1} \mathrm{H}$ and ${ }^{13} \mathrm{C}\left\{{ }^{1} \mathrm{H}\right\}$ NMR spectra of $\mathbf{3 b}, \mathbf{c}$ (toluene- $d_{8}$ ) do not exhibit the above-mentioned temperature dependence for $3 \mathbf{a}$ at the temperatures studied $\left(-60\right.$ to $25{ }^{\circ} \mathrm{C}$ ). On the basis of the above discussion of $\mathbf{3 a}$ compounds $\mathbf{3} \mathbf{b}, \mathbf{c}$ are expected to exist in solution as $\Lambda S S$ or the $\Delta S S$ diastereoisomers (see Figure 5), i.e. exhibiting two ${ }^{1} \mathrm{H}$ and ${ }^{13} \mathrm{C}$ NMR resonance patterns. Most interestingly, only one resonance pattern is observed, which suggests that only one diastereoisomer is present in solution over a wide temperature range: i.e., the inversion process, operative in $\mathbf{3 a}$, is blocked in $\mathbf{3 b}, \mathbf{c}$, resulting in the presence of either the $\Lambda S S$ or the $\Delta S S$ diastereoisomer. It is conceivable that steric interference between the bulky ring substituents $i \operatorname{Pr}(\mathbf{3 b})$ and $t \mathrm{Bu}(\mathbf{3 c})$ lock the wagging process about the $\mathrm{C}(4)-\mathrm{C}_{i p s o}-\mathrm{C}_{i p s o}^{\prime}-\mathrm{C}(24)$ axis, leading to the stabilization of one diastereoisomer over the other.

Both ${ }^{1} \mathrm{H}$ and ${ }^{7} \mathrm{Li}$ NMR signals of $\mathbf{3 a}$ are insensitive to the addition of 1 equiv of diethyl ether, THF, or triethylamine. This suggests that the dimeric structure is not disrupted by these simple bases, and hence, stronger coordination of the bis(oxazoline) substituents is implied.

(16) Friebolin, H. Basic One- and Two-Dimensional NMR Spectroscopy; Wiley-VCH: Weinheim, Germany, 1998. 


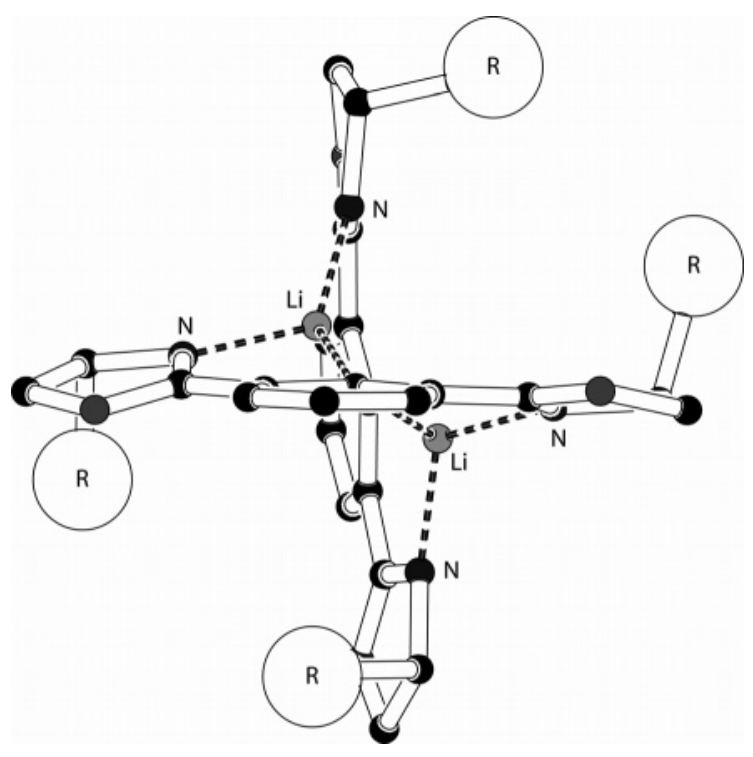

Figure 5. Schematic representation of the structure of one of the proposed diastereoisomers $(\Lambda S S)$ of $\mathbf{3 b}, \mathbf{c}$.

\section{Conclusions}

The synthesis and structural features of $[\mathrm{Sn}(\mathrm{Me}, \mathrm{Me}-$ Phebox) $\left.\mathrm{Me}_{3}\right](\mathbf{2})$ and $\left[\mathrm{Li}\left(\mathrm{R}, \mathrm{R}^{\prime}\right.\right.$-Phebox $\left.)\right]$ complexes $\mathbf{3 a}(\mathrm{R}$ $\left.=\mathrm{R}^{\prime}=\mathrm{Me}\right), \mathbf{3 b}\left(\mathrm{R}=i \mathrm{Pr}, \mathrm{R}^{\prime}=\mathrm{H}\right)$, and $\mathbf{3 c}\left(\mathrm{R}=t \mathrm{Bu}, \mathrm{R}^{\prime}\right.$ $=\mathrm{H}$ ) were investigated. It was found that the Phebox ligand in 2 is $\eta^{1}(\mathrm{C})$-bonded to the $\mathrm{Sn}$ center: i.e., no chelation of the bis(oxazoline) substituents occurs. The $\left[\mathrm{Li}\left(\mathrm{R}, \mathrm{R}^{\prime}\right.\right.$-Phebox $\left.)\right]$ complex $\mathbf{3 a}\left(\mathrm{R}=\mathrm{R}^{\prime}=\mathrm{Me}\right)$ exists both in solution $\left({ }^{13} \mathrm{C} N M R\right)$ and in the solid state (X-ray) as a dimer containing formal three-center-two-electron bonds in a $\mathrm{Li}_{2} \mathrm{C}_{2}$ central ring. The Phebox ligand is $\eta^{3}$ (N,C,N)-bonded to the lithium centers, presenting the first structurally characterized aryllithium complex containing intramolecular imine $\mathrm{N}$-lithium coordination. The $\left[\mathrm{Li}\left(\mathrm{R}, \mathrm{R}^{\prime}\right.\right.$-Phebox $\left.)\right]$ complexes can be prepared in high yield and are excellent starting materials for the preparation of $\mathrm{R}, \mathrm{R}^{\prime}$-Phebox-metal complexes which can be used as transmetalating reagents ([Au( $\mathrm{Me}, \mathrm{Me}-$ Phebox $\left.\left.)\left(\mathrm{PPh}_{3}\right)\right],{ }^{17 \mathrm{a}}\left[(\mathrm{Au}(\mathrm{Me}, \mathrm{Me}-\mathrm{Phebox}))_{2}(\mathrm{dppbp})\right]\right)^{17 \mathrm{~b}}$ and

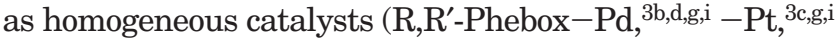
$\left.-\mathrm{Rh}^{3 \mathrm{e}, \mathrm{f}, \mathrm{h}}\right)$.

\section{Experimental Section}

All experiments were carried out under a dry, oxygen-free nitrogen atmosphere, using standard Schlenk techniques. Solvents were dried and distilled from sodium (pentane, toluene), $\mathrm{Na}$ /benzophenone (diethyl ether, tetrahydrofuran), $\mathrm{CaH}_{2}\left(\mathrm{CH}_{2} \mathrm{Cl}_{2}, \mathrm{CH}_{3} \mathrm{CN}\right)$, or $\mathrm{KOH}\left(\mathrm{Et}_{3} \mathrm{~N}\right)$ prior to use. $n$ - $\mathrm{BuLi}$ (1.6 $\mathrm{M}$ in hexanes) was supplied by Acros and used as received. ${ }^{1} \mathrm{H}$ and ${ }^{13} \mathrm{C}\left\{{ }^{1} \mathrm{H}\right\}$ NMR spectra were recorded on a Varian Inova 300 spectrometer. ${ }^{7} \mathrm{Li} \mathrm{NMR}$ (5 mm tube) and NMR experiments with diethyl ether, tetrahydrofuran, and triethylamine (10 $\mathrm{mm}$ tube) were recorded on a Varian Mercury 200 spectrometer. Benzene- $d_{6}$ and toluene- $d_{8}$ were purchased from Cambridge Isotope Laboratories, distilled from $\mathrm{Na}$, and stored in a nitrogen-filled M. Braun glovebox. Other NMR solvents (acetone- $d_{6}, \mathrm{CDCl}_{3}$ ) were used as received. Chemical shifts $(\delta)$ are reported in ppm relative to the residual solvent signal as an internal standard. The ${ }^{7} \mathrm{Li}$ NMR spectra are referenced to

(17) (a) Stol, M.; Lutz, M.; Spek, A. L.; van Klink, G. P. M.; van Koten, G. To be submitted for publication. (b) Stol, M.; Snelders, D. M.; Kooijman, H.; Spek, A. L.; van Klink, G. P. M.; van Koten, G. To be submitted for publication.
$\mathrm{LiCl}(1.0 \mathrm{M})$ in $\mathrm{D}_{2} \mathrm{O}$ as an external standard. 2-Bromoisophthalic acid, ${ }^{6 a}$ L-valinol, and L-tert-leucinol ${ }^{18}$ were synthesized according to literature procedures. ( $R, \mathrm{R}^{\prime}$-Phebox)Br was synthesized according to a combination of literature procedures. ${ }^{3 \mathrm{e}, 6}$ All other chemicals were purchased from either Acros or Aldrich and used as received. Elemental analysis were performed by Kolbe, Mikroanalytisches Laboratorium, Mülheim/ Ruhr, Germany.

Synthesis of [R,R'-PheboxBr] Compounds. (a) [Me,MePheboxBr] (1a). Thionyl chloride (12 mL, $164 \mathrm{mmol})$ was added to 2-bromoisophthalic acid $(9.8 \mathrm{~g}, 40 \mathrm{mmol})$. The mixture was refluxed overnight, and the residual $\mathrm{SOCl}_{2}$ was removed in vacuo. A portion of the resulting 2-bromoisophthalic acid chloride $(6.9 \mathrm{~g}, 25 \mathrm{mmol})$ was weighed into a $500 \mathrm{~mL}$ onenecked round-bottom flask, equipped with a nitrogen inlet. The acid was dissolved in $\mathrm{CH}_{2} \mathrm{Cl}_{2}(25 \mathrm{~mL})$, and the temperature of the flask was reduced to $0{ }^{\circ} \mathrm{C}$ (ice/water bath). In a separate Schlenk vessel, 2-amino-2-methyl-1-propanol (5.07 g, 56.3 $\mathrm{mmol})$ and $\mathrm{NEt}_{3}(13.9 \mathrm{~mL}, 100 \mathrm{mmol})$ were dissolved in $\mathrm{CH}_{2-}$ $\mathrm{Cl}_{2}$ (35 mL) and slowly added by syringe to the cooled 2-bromoisophthalic acid chloride solution. The reaction mixture was stirred overnight, after which time the solvent was removed in vacuo. Acetonitrile $(200 \mathrm{~mL}), \mathrm{PPh}_{3}(23.7 \mathrm{~g}, 90.6$ $\mathrm{mmol})$, and $\mathrm{Et}_{3} \mathrm{~N}(15.0 \mathrm{~mL}, 108 \mathrm{mmol})$ were added to the residue. The temperature was reduced to $0{ }^{\circ} \mathrm{C}$, after which time $\mathrm{CCl}_{4}(20.7 \mathrm{~mL}, 215 \mathrm{mmol})$ was slowly added via a syringe. After it was stirred overnight, the mixture was quenched with $\mathrm{H}_{2} \mathrm{O}(10 \mathrm{~mL})$ and the volatiles were removed in vacuo. The residue was dissolved in $\mathrm{H}_{2} \mathrm{O}(200 \mathrm{~mL})$ and ethyl acetate (200 $\mathrm{mL}$ ). After separation of the layers, the organic layer was washed with $\mathrm{H}_{2} \mathrm{O}(100 \mathrm{~mL})$. The combined aqueous layers were extracted with ethyl acetate $(3 \times 100 \mathrm{~mL})$, dried $\left(\mathrm{MgSO}_{4}\right)$, and filtered. After the solvent was removed in vacuo, the residue was stirred for $3 \mathrm{~h}$ in $\mathrm{Et}_{2} \mathrm{O}(250 \mathrm{~mL})$. The suspension was filtered, the residue was washed with additional $\mathrm{Et}_{2} \mathrm{O}(200$ $\mathrm{mL}$ ), and the filtrate was dried in vacuo. The crude product was filtered over alumina (neutral Merck 90: $\mathrm{Et}_{2} \mathrm{O} ; R_{f} 0.25$ ), resulting in the recovery of $6.95 \mathrm{~g}(20 \mathrm{mmol}, 81 \%)$ of the white solid product. ${ }^{1} \mathrm{H}$ NMR $\left(300 \mathrm{MHz}\right.$, acetone- $\left.d_{6}\right)$ : $\delta 1.35(\mathrm{~s}, 12$ $\left.\mathrm{H}, \mathrm{CMe}_{2}\right), 4.14\left(\mathrm{~s}, 4 \mathrm{H}, \mathrm{CH}_{2}\right), 7.52\left(\mathrm{t}, 1 \mathrm{H},{ }^{3} J_{\mathrm{H}-\mathrm{H}}=7.7 \mathrm{~Hz}, \mathrm{Ar}\right.$ $H), 7.67\left(\mathrm{~d}, 2 \mathrm{H},{ }^{3} J_{\mathrm{H}-\mathrm{H}}=7.5 \mathrm{~Hz}, \mathrm{Ar} H\right) .{ }^{13} \mathrm{C}\left\{{ }^{1} \mathrm{H}\right\} \mathrm{NMR}(75 \mathrm{MHz}$, acetone- $\left.d_{6}\right): \delta 28.4\left(\mathrm{CMe}_{2}\right), 69.1\left(\mathrm{CMe}_{2}\right), 79.9\left(\mathrm{OCH}_{2}\right), 121.7$ $(\operatorname{Ar} C), 128.1(\operatorname{Ar} C), 133.2(\operatorname{Ar} C), 133.7(\operatorname{Ar} C), 161.7(\mathrm{OCN})$. Anal. Calcd for $\mathrm{C}_{16} \mathrm{H}_{19} \mathrm{BrN}_{2} \mathrm{O}_{2}$ : C, 54.71; H, 5.45; N, 7.98. Found: C, 54.63; H, 5.38; N, 7.96.

Synthesis of $[(\boldsymbol{S}, \boldsymbol{S})$-iPr,H-PheboxBr] $(\mathbf{1 b})$. A procedure analogous to the synthesis of $\mathbf{1 a}$ was employed using 2-bromoisophthalic acid $(5.05 \mathrm{~g}, 21 \mathrm{mmol})$ and L-valinol $(4.91 \mathrm{~g}, 48$ $\mathrm{mmol})$, giving a light yellow oil. Yield: $5.16 \mathrm{~g}(67 \%) . R_{f}$ value $\left(\mathrm{Et}_{2} \mathrm{O}\right): 0.28 .[\alpha]^{20}{ }_{\mathrm{D}}=-63.2^{\circ}\left(c=0.10 \mathrm{~g} / \mathrm{mL}, \mathrm{CH}_{2} \mathrm{Cl}_{2}\right) .{ }^{1} \mathrm{H}$ NMR $\left(300 \mathrm{MHz}, \mathrm{CDCl}_{3}\right): \delta 0.98\left(\mathrm{~d}, 6 \mathrm{H},{ }^{3} J_{\mathrm{H}-\mathrm{H}}=6.6 \mathrm{~Hz}, \mathrm{CHM} e_{2}\right)$, $1.04\left(\mathrm{~d}, 6 \mathrm{H},{ }^{3} J_{\mathrm{H}-\mathrm{H}}=6.6 \mathrm{~Hz}, \mathrm{CHM} e_{2}\right), 1.91$ (septet, $2 \mathrm{H},{ }^{3} J_{\mathrm{H}-\mathrm{H}}$ $=6.6 \mathrm{~Hz}, \mathrm{CHMe}), 4.18\left(\mathrm{~m}, 4 \mathrm{H}, \mathrm{OCH}_{2}\right), 4.45(\mathrm{~m}, 2 \mathrm{H}, \mathrm{CHN})$, $7.37\left(\mathrm{t}, 1 \mathrm{H},{ }^{3} \boldsymbol{J}_{\mathrm{H}-\mathrm{H}}=7.7 \mathrm{~Hz}, \operatorname{Ar} H\right), 7.65\left(\mathrm{~d}, 2 \mathrm{H},{ }^{3} J_{\mathrm{H}-\mathrm{H}}=7.8\right.$ $\mathrm{Hz}, \mathrm{Ar} H) .{ }^{13} \mathrm{C}\left\{{ }^{1} \mathrm{H}\right\} \mathrm{NMR}\left(\mathrm{CDCl}_{3}, 75 \mathrm{MHz}\right): \delta 32.3\left(\mathrm{CMe}_{2}\right), 60.0$ $\left(\mathrm{CMe}_{2}\right), 70.2(\mathrm{CHN}), 72.6\left(\mathrm{OCH}_{2}\right), 121.0(\mathrm{Ar} C), 126.6(\mathrm{Ar} C)$, 132.0 (Ar C), $132.2(\operatorname{Ar} C), 162.6(\mathrm{OCN})$. Anal. Calcd for $\mathrm{C}_{18} \mathrm{H}_{23}$ $\mathrm{BrN}_{2} \mathrm{O}_{2}$ : C, 57.00; H, 6.11; N, 7.39. Found: C, 56.88; H, 6.07; $\mathrm{N}, 7.26$.

Synthesis of $[(S, S) t$ Bu,H-PheboxBr] (1c). A procedure analogous to the synthesis of $\mathbf{1 a}$ was employed using 2-bromoisophthalic acid $(4.1 \mathrm{~g}, 15 \mathrm{mmol})$ and L-tert-leucinol (3.5 g, 30 $\mathrm{mmol})$, giving a colorless oil. Yield: $4.31 \mathrm{~g} \mathrm{(73 \% ).} R_{f}$ value (1:1 diethyl ether/ethyl acetate): $0.71 .[\alpha]^{20}{ }_{\mathrm{D}}=-60.2^{\circ}(c=0.11$ $\mathrm{g} / \mathrm{mL}, \mathrm{EtOH}) .{ }^{1} \mathrm{H}$ NMR $\left(300 \mathrm{MHz}, \mathrm{CDCl}_{3}\right): \delta 0.96(\mathrm{~s}, 18 \mathrm{H}$, $\left.\mathrm{CMe}_{3}\right), 4.06\left(\mathrm{dd}, 2 \mathrm{H},{ }^{3} \boldsymbol{J}_{\mathrm{H}-\mathrm{H}}=10.1 \mathrm{~Hz},{ }^{3} \boldsymbol{J}_{\mathrm{H}-\mathrm{H}}=8.3 \mathrm{~Hz}, \mathrm{OCH}_{2}\right)$, $4.22\left(\mathrm{t}, 2 \mathrm{H},{ }^{3} J_{\mathrm{H}-\mathrm{H}}=8.7 \mathrm{~Hz}, \mathrm{CHN}\right), 4.37\left(\mathrm{dd}, 1 \mathrm{H},{ }^{3} J_{\mathrm{H}-\mathrm{H}}=10.1\right.$ $\left.\mathrm{Hz},{ }^{3} J_{\mathrm{H}-\mathrm{H}}=8.9 \mathrm{~Hz}, \mathrm{OCH}_{2}\right), 7.33\left(\mathrm{t}, 1 \mathrm{H},{ }^{3} \boldsymbol{J}_{\mathrm{H}-\mathrm{H}}=7.7 \mathrm{~Hz}, \mathrm{Ar}\right.$

(18) McKennon, M. J.; Meyers, A. I. J. Org. Chem. 1993, 58, 35683571. 
$H), 7.60\left(\mathrm{~d}, 2 \mathrm{H},{ }^{3} J_{\mathrm{H}-\mathrm{H}}=7.2 \mathrm{~Hz}, \operatorname{Ar} H\right) \cdot{ }^{13} \mathrm{C}\left\{{ }^{1} \mathrm{H}\right\} \mathrm{NMR}(75 \mathrm{MHz}$, $\left.\mathrm{CDCl}_{3}\right): \delta 26.1\left(\mathrm{CMe}_{3}\right), 34.0\left(\mathrm{CMe}_{3}\right), 69.2(\mathrm{CHN}), 76.7\left(\mathrm{OCH}_{2}\right)$, 121.4 (Ar $C$ ), 127.0 ( $\operatorname{Ar} C$ ), $132.4(\operatorname{Ar} C$ ), 132.6 (Ar $C$ ), 163.0 (OCN). Anal. Calcd for $\mathrm{C}_{20} \mathrm{H}_{27} \mathrm{BrN}_{2} \mathrm{O}_{2}$ : C, 58.97; $\mathrm{H}, 6.68 ; \mathrm{N}$, 6.88. Found: C, 59.10; H, 6.74; N, 6.76.

Synthesis of [Sn(Me,Me-Phebox)Me $\mathbf{M e}_{3}$ (2). A portion of $n$-BuLi $(0.70 \mathrm{~mL}, 1.1 \mathrm{mmol}, 1.6 \mathrm{M}$ solution in hexanes) was added to a solution of $\mathbf{1 a}(0.35 \mathrm{~g}, 1.0 \mathrm{mmol})$ in an appropriate solvent $(20 \mathrm{~mL}$, THF, diethyl ether, pentane, or toluene; Scheme 1) at $-78^{\circ} \mathrm{C}$. After the solution was stirred and slowly warmed to room temperature, $\mathrm{SnClMe}_{3}(2.8 \mathrm{~mL}, 1.0 \mathrm{mmol}$, $0.36 \mathrm{M}$ solution in pentane) was added, and the resulting mixture was stirred for $1 \mathrm{~h}$. The mixture was then quenched with water $(10 \mathrm{~mL})$ and the layers separated. The organic layer was washed with $\mathrm{H}_{2} \mathrm{O}(10 \mathrm{~mL})$, dried $\left(\mathrm{Na}_{2} \mathrm{SO}_{4}\right)$, and filtered, and the solvent was removed in vacuo. A yellow oil was obtained, which crystallized rapidly. The yields in the following solvents were as follows: THF (97\%), diethyl ether $(97 \%)$, pentane $(98 \%)$, toluene $(99 \%) .{ }^{1} \mathrm{H}$ NMR $\left(300 \mathrm{MHz}, \mathrm{C}_{6} \mathrm{D}_{6}\right): \delta$ $0.46\left(\mathrm{~s}, 9 \mathrm{H},{ }^{117} \mathrm{Sn}(7.7 \%)\right.$ and ${ }^{119} \mathrm{Sn}(8.4 \%)$ satellites, ${ }^{2} \mathrm{~J}=26.7$ $\mathrm{Hz}, 27.8 \mathrm{~Hz}, \mathrm{SnMe} e_{3}$ ), 1.17 (s, $12 \mathrm{H}, \mathrm{CMe}$ ), 3.67 (s, 4H, $\mathrm{OCH}_{2}$ ), $8.11\left(\mathrm{t}, 1 \mathrm{H},{ }^{3} J_{\mathrm{H}-\mathrm{H}}=7.8 \mathrm{~Hz}, \operatorname{Ar} H\right), 7.96\left(\mathrm{~d}, 2 \mathrm{H},{ }^{3} J_{\mathrm{H}-\mathrm{H}}=\right.$ $7.5 \mathrm{~Hz}, \mathrm{Ar} H) .{ }^{13} \mathrm{C}\left\{{ }^{1} \mathrm{H}\right\}$ NMR $\left(75 \mathrm{MHz}, \mathrm{CDCl}_{3}\right): \delta-2.0$ $\left({ }^{1} J\left({ }^{117,119} \mathrm{Sn}-{ }^{13} \mathrm{C}\right)=190 \mathrm{~Hz}, \mathrm{SnMe} e_{3}\right), 28.6\left(\mathrm{CMe}_{2}\right), 68.1\left(\mathrm{CMe}_{2}\right)$, $79.2\left(\mathrm{OCH}_{2}\right), 128.0(\mathrm{Ar} C), 131.3\left({ }^{1} J\left({ }^{117,119} \mathrm{Sn}-{ }^{13} \mathrm{C}\right)=16 \mathrm{~Hz}\right.$, Ar $C$ ), 137.0 (Ar C), 148.2 (Ar C), 163.6 (OCN). Anal. Calcd for $\mathrm{C}_{19} \mathrm{H}_{28} \mathrm{~N}_{2} \mathrm{O}_{2} \mathrm{Sn}$ : C, 52.44; H, 6.49; N, 6.44. Found: C, 52.53; $\mathrm{H}, 6.57$; N, 6.37.

Synthesis of [Li(Me,Me-Phebox) $]_{2}$ (3a). To a solution of $\mathbf{1 a}(1.01 \mathrm{~g}, 2.89 \mathrm{mmol})$ in pentane $(50 \mathrm{~mL})$ was added $n-\mathrm{BuLi}$ (1.8 mL, $2.9 \mathrm{mmol}, 1.6 \mathrm{M}$ in hexane) at $-78^{\circ} \mathrm{C}$. The reaction mixture was warmed to room temperature and stirred for 3 $\mathrm{h}$, after which the volatile components were removed in vacuo. The residue was washed twice with pentane $(4 \mathrm{~mL})$, which afforded an off-white solid product (yield: $531 \mathrm{mg}, 66 \%$ ). ${ }^{1} \mathrm{H}$ NMR $\left(300 \mathrm{MHz}, \mathrm{C}_{6} \mathrm{D}_{6}\right): \delta 0.92\left(\mathrm{~s}, 12 \mathrm{H}, \mathrm{CMe}_{2}\right), 3.76(\mathrm{~s}, 4 \mathrm{H}$, $\left.\mathrm{OCH}_{2}\right), 7.20\left(\mathrm{t}, 1 \mathrm{H},{ }^{3} J_{\mathrm{H}-\mathrm{H}}=7.7 \mathrm{~Hz}, \operatorname{Ar} H\right), 8.09\left(\mathrm{~d}, 2 \mathrm{H},{ }^{3} J_{\mathrm{H}-\mathrm{H}}\right.$ $=7.8 \mathrm{~Hz}, \mathrm{Ar} H) .{ }^{13} \mathrm{C}\left\{{ }^{1} \mathrm{H}\right\} \mathrm{NMR}\left(75 \mathrm{MHz}, \mathrm{C}_{6} \mathrm{D}_{6}\right): \delta 28.4(\mathrm{CMe} 2)$, $65.6\left(\mathrm{CMe}_{2}\right), 79.9\left(\mathrm{OCH}_{2}\right), 124.0(\mathrm{Ar} \mathrm{C}), 127.7(\mathrm{Ar} \mathrm{C}), 139.7$ $(\mathrm{Ar} C), 172.2(\mathrm{OCN}), 199.4\left(\right.$ septet, ${ }^{1} J\left({ }^{13} \mathrm{C},{ }^{7} \mathrm{Li}\right)=17.7 \mathrm{~Hz}, \mathrm{Ar}$ $C) .{ }^{7} \mathrm{Li}$ NMR $\left(78 \mathrm{MHz}\right.$, toluene- $\left.d_{8}\right)$ : $\delta$ 1.50. Anal. Calcd for $\mathrm{C}_{16} \mathrm{H}_{19} \mathrm{LiN}_{2} \mathrm{O}_{2}$ : C, 69.06; H, 6.88; N, 10.07. Found: C, 68.83; $\mathrm{H}, 6.95 ; \mathrm{N}, 9.83$.

Synthesis of $[\mathrm{Li}(i \mathrm{Pr}, \mathrm{H}-\mathrm{Phebox})]_{2}(3 \mathrm{~b})$. To a solution of $1 \mathbf{b}(0.47 \mathrm{~g}, 1.24 \mathrm{mmol})$ in pentane $(25 \mathrm{~mL})$ was added $n$-BuLi $(0.9 \mathrm{~mL}, 1.44 \mathrm{mmol}, 1.6 \mathrm{M}$ in hexane) at a temperature of -78 ${ }^{\circ} \mathrm{C}$. The reaction mixture was warmed to room temperature and stirred for $4 \mathrm{~h}$, after which the suspension was decanted after centrifugation. The residue was washed with pentane $(10 \mathrm{~mL})$, which afforded a white solid product (yield: $370 \mathrm{mg}$, $98 \%) .{ }^{1} \mathrm{H}$ NMR $\left(300 \mathrm{MHz}\right.$, toluene- $\left.d_{8}\right): \delta 0.63\left(\mathrm{~d}, 6 \mathrm{H},{ }^{3} J_{\mathrm{H}-\mathrm{H}}=\right.$ $\left.6.6 \mathrm{~Hz}, \mathrm{CHM} e_{2}\right), 0.70\left(\mathrm{~d},{ }^{3} J_{\mathrm{H}-\mathrm{H}}=6.6 \mathrm{~Hz}, \mathrm{CHM} e_{2}\right), 1.41(\mathrm{sp}$, $2 \mathrm{H},{ }^{3} J_{\mathrm{H}-\mathrm{H}}=6.6 \mathrm{~Hz}, \mathrm{CH} \mathrm{Me}_{2}$ ), 3.76, 4.02, 4.06 (ABX pattern, $6 \mathrm{H},{ }^{2} J_{\mathrm{H}-\mathrm{H}}(\mathrm{AB})=8.4 \mathrm{~Hz},{ }^{3} J_{\mathrm{H}-\mathrm{H}}(\mathrm{AX}+\mathrm{BX})=15.8 \mathrm{~Hz}, \mathrm{OCH}_{2}$, $\mathrm{NCH}) 7.21\left(\mathrm{t}, 1 \mathrm{H},{ }^{3} J_{\mathrm{H}-\mathrm{H}}=7.8 \mathrm{~Hz}, \mathrm{Ar} H\right), 8.04\left(\mathrm{~d},{ }^{3} J_{\mathrm{H}-\mathrm{H}}=7.8\right.$ $\mathrm{Hz}, \mathrm{Ar} H) .{ }^{13} \mathrm{C}\left\{{ }^{1} \mathrm{H}\right\}$ NMR $\left(75 \mathrm{MHz}, \mathrm{C}_{6} \mathrm{D}_{6}\right): \delta 18.5\left(\mathrm{CHM} e_{2}\right)$, $18.9\left(\mathrm{CHMe}_{2}\right), 33.4\left(\mathrm{CHMe}_{2}\right), 71.4(\mathrm{NCH}), 71.6\left(\mathrm{OCH}_{2}\right), 124.2$ (Ar C), $128.6(\operatorname{Ar} C)$ ) $139.7(\operatorname{Ar} C), 173.9(\mathrm{OCN}), 198.8$ (sp, $\left.\left.{ }^{1} J\left({ }^{13} \mathrm{C},{ }^{7} \mathrm{Li}\right)=17.6 \mathrm{~Hz}, \mathrm{Ar} C\right).\right) .{ }^{7} \mathrm{Li} \mathrm{NMR}\left(78 \mathrm{MHz}\right.$, toluene- $\left.d_{8}\right)$ : $\delta$ 1.64. Anal. Calcd for $\mathrm{C}_{19} \mathrm{H}_{23} \mathrm{LiN}_{2} \mathrm{O}_{2}: \mathrm{C}, 70.58 ; \mathrm{H}, 7.57 ; \mathrm{N}$, 9.14. Found: C, 70.15; H, 7.49; N, 8.86.

Synthesis of $[\mathrm{Li}(t \mathrm{Bu}, \mathrm{H}-\mathrm{Phebox})]_{2}(3 \mathrm{c})$. To a solution of $1 c(0.24 \mathrm{~g}, 0.59 \mathrm{mmol})$ in diethyl ether $(20 \mathrm{~mL})$ was added $n$ - $\mathrm{BuLi}\left(0.5 \mathrm{~mL}, 0.8 \mathrm{mmol}, 1.6 \mathrm{M}\right.$ in hexane) at $-78{ }^{\circ} \mathrm{C}$. The reaction mixture was stirred at this temperature for $45 \mathrm{~min}$, after which time it was warmed to room temperature and stirred for another $3 \mathrm{~h}$. The volatile components of the mixture were then removed in vacuo. The residue was washed with pentane $(2 \times 5 \mathrm{~mL})$, which afforded a white solid product (yield: $83 \mathrm{mg}, 42 \%) .{ }^{1} \mathrm{H} \mathrm{NMR}\left(300 \mathrm{MHz}\right.$, toluene- $\left.d_{8}\right): \delta 0.67$ (s, $\left.18 \mathrm{H}, \mathrm{CMe}_{3}\right), 3.79,4.067,4.116\left(\mathrm{ABX}\right.$ pattern, $6 \mathrm{H},{ }^{2} J_{\mathrm{H}-\mathrm{H}}(\mathrm{AB})$
Table 1. Crystallographic Data for Crystal Structure Determinations of 2 and $3 \mathrm{a}$

\begin{tabular}{|c|c|c|}
\hline & 2 & 3a \\
\hline formula & $\mathrm{C}_{19} \mathrm{H}_{28} \mathrm{~N}_{2} \mathrm{O}_{2} \mathrm{Sn}$ & $\mathrm{C}_{32} \mathrm{H}_{38} \mathrm{Li}_{2} \mathrm{~N}_{4} \mathrm{O}_{4}$ \\
\hline mol wt & 435.15 & 556.54 \\
\hline cryst syst & monoclinic & monoclinic \\
\hline space group & $P 2_{1} / c$ (No. 14$)$ & $P 2_{1} / c$ (No. 14 ) \\
\hline$a(\AA)$ & $11.1077(10)$ & $11.4446(10)$ \\
\hline$b(\AA)$ & $11.3324(10)$ & $17.530(2)$ \\
\hline$c(\AA)$ & $18.4916(19)$ & $17.622(3)$ \\
\hline$\beta$ (deg) & $121.130(6)$ & $115.945(11)$ \\
\hline$V\left(\AA^{3}\right)$ & $1992.5(3)$ & $3179.1(7)$ \\
\hline$D_{\text {calcd }}\left(\mathrm{g} \mathrm{cm}^{-3}\right)$ & $1.4506(2)$ & $1.1628(3)$ \\
\hline$Z$ & 4 & 4 \\
\hline$F(000)$ & 888 & 1184 \\
\hline$\mu(\mathrm{Mo} \mathrm{K} \alpha)\left(\mathrm{mm}^{-1}\right)$ & 1.295 & 0.076 \\
\hline cryst color & colorless & pale yellow \\
\hline cryst size (mm) & $0.15 \times 0.30 \times 0.30$ & $0.2 \times 0.3 \times 0.3$ \\
\hline$\theta_{\min }, \theta_{\max }(\mathrm{deg})$ & $1.0,27.6$ & $1.0,27.5$ \\
\hline $\begin{array}{l}\text { dist from cryst to } \\
\text { detector (mm) }\end{array}$ & 50 & 40 \\
\hline data set $(h k l)$ & $\begin{array}{l}-14 \text { to }+14, \\
\quad-14 \text { to }+14 \\
-24 \text { to }+23\end{array}$ & $\begin{array}{l}-14 \text { to }+14 \\
\quad-22 \text { to }+22 \\
-22 \text { to }+22\end{array}$ \\
\hline abs cor range & $0.596-0.875$ & \\
\hline $\begin{array}{l}\text { total no. of data, } \\
\text { no. of unique data }\end{array}$ & 39706,4589 & 82804,7294 \\
\hline$R_{\text {int }}$ & 0.1012 & 0.1016 \\
\hline $\begin{array}{l}\text { no. of refined } \\
\text { params }\end{array}$ & 224 & 387 \\
\hline final $R 1^{a}$ & $\begin{array}{l}0.0242(4199 \\
I>2 \sigma(I))\end{array}$ & $\begin{array}{c}0.0493(5095 \\
I>2 \sigma(I))\end{array}$ \\
\hline final wR2 $2^{b}$ & 0.0627 & 0.1275 \\
\hline goodness of fit & 1.029 & 1.034 \\
\hline $\mathrm{w}^{-1 c}$ & $\begin{array}{l}\sigma^{2}\left(F_{0}^{2}\right)+(0.0313 P)^{2}+ \\
0.89 P\end{array}$ & $\begin{array}{l}\sigma^{2}\left(F_{0}^{2}\right)+(0.0506 P)^{2}+ \\
\quad 1.00 P\end{array}$ \\
\hline $\begin{array}{l}\text { min, max residual } \\
\text { density }\left(\mathrm{e} \AA^{-3}\right)\end{array}$ & $\begin{array}{l}-1.14,0.93 \\
\text { (near Sn) }\end{array}$ & $-0.24,0.22$ \\
\hline
\end{tabular}

$\left.=8.4 \mathrm{~Hz},{ }^{3} J_{\mathrm{H}-\mathrm{H}}(\mathrm{AX}+\mathrm{BX})=19.8 \mathrm{~Hz}, \mathrm{OCH}_{2}, \mathrm{NCH}\right), 7.23(\mathrm{t}$, $\left.1 \mathrm{H},{ }^{3} \boldsymbol{J}_{\mathrm{H}-\mathrm{H}}=7.7 \mathrm{~Hz}, \operatorname{Ar} H\right), 8.14\left(2 \mathrm{H},{ }^{3} \boldsymbol{J}_{\mathrm{H}-\mathrm{H}}=7.8 \mathrm{~Hz}, \operatorname{Ar} H\right)$. ${ }^{13} \mathrm{C}\left\{{ }^{1} \mathrm{H}\right\}$ NMR $\left(75 \mathrm{MHz}, \mathrm{C}_{6} \mathrm{D}_{6}\right): \delta 26.0\left(\mathrm{CMe}_{3}\right), 33.4\left(\mathrm{CMe}_{3}\right)$, $69.4(\mathrm{NCH}), 75.4\left(\mathrm{OCH}_{2}\right), 124.1(\mathrm{Ar} C), 128.4(\mathrm{Ar} C), 139.7(\mathrm{Ar}$ C), $173.8(\mathrm{OCN}), 198.1\left(\mathrm{sp},{ }^{1} J\left({ }^{13} \mathrm{C},{ }^{7} \mathrm{Li}\right)=17.8 \mathrm{~Hz}, \operatorname{Ar} C\right) .{ }^{7} \mathrm{Li}$ NMR (78 MHz, toluene- $\left.d_{8}\right)$ : $\delta$ 1.74. Anal. Calcd for $\mathrm{C}_{20} \mathrm{H}_{27-}$ $\mathrm{LiN}_{2} \mathrm{O}_{2}$ : C, 71.84; H, 8.14; N, 8.38. Found: C, 71.64; H, 8.02; $\mathrm{N}, 8.22$.

NMR Experiments of 3a with Subsequent Addition of Diethyl Ether, Tetrahydrofuran, and Triethylamine. In a nitrogen-filled glovebox, $\mathbf{3 a}(128 \mathrm{mg}, 0.46 \mathrm{mmol})$ was weighed in a $10 \mathrm{~mm}$ NMR tube and dissolved in toluene- $d_{8}$. After the NMR spectra were recorded without additional coordinating solvents present, the NMR tube was placed under nitrogen in a modified Schlenk tube and $\mathrm{Et}_{2} \mathrm{O}(45 \mu \mathrm{L}, 0.46 \mathrm{mmol})$ was added. ${ }^{1} \mathrm{H},{ }^{7} \mathrm{Li}\left\{{ }^{1} \mathrm{H}\right\}$, and ${ }^{13} \mathrm{C}\left\{{ }^{1} \mathrm{H}\right\}$ NMR spectra were recorded at room temperature and ${ }^{1} \mathrm{H}$ and ${ }^{7} \mathrm{Li}\left\{{ }^{1} \mathrm{H}\right\}$ NMR spectra at -60 ${ }^{\circ} \mathrm{C}$. The NMR tube was again placed under nitrogen before adding THF (40 $\mu \mathrm{L}, 0.49 \mathrm{mmol}$ ) to the mixture. ${ }^{1} \mathrm{H}$ and ${ }^{7} \mathrm{Li}$ NMR spectra were again recorded at $-60{ }^{\circ} \mathrm{C}$ and at room temperature. Following the same procedure, $\mathrm{Et}_{3} \mathrm{~N}(65 \mu \mathrm{L}, 0.47$ mmol) was added to the mixture and ${ }^{1} \mathrm{H}$ and ${ }^{7} \mathrm{Li}\left\{{ }^{1} \mathrm{H}\right\}$ spectra were recorded of the mixture at room temperature. No change was observed in the chemical shift of the ${ }^{7} \mathrm{Li}$ signal for $\mathbf{3 a}$ ${ }^{7} \mathrm{Li}\left\{{ }^{1} \mathrm{H}\right\} \mathrm{NMR}\left(78 \mathrm{MHz}\right.$, toluene- $\left.d_{8}, \mathrm{Et}_{2} \mathrm{O}\right): 298 \mathrm{~K}, \delta 1.48 ; 213$ $\mathrm{K}, \delta 1.50 .{ }^{7} \mathrm{Li}\left\{{ }^{1} \mathrm{H}\right\} \mathrm{NMR}\left(78 \mathrm{MHz}\right.$, toluene- $\left.d_{8}, \mathrm{Et}_{2} \mathrm{O}, \mathrm{THF}\right): 298$ $\mathrm{K}, \delta 1.48 ; 213 \mathrm{~K}, \delta 1.48 .{ }^{7} \mathrm{Li}\left\{{ }^{1} \mathrm{H}\right\} \mathrm{NMR}\left(78 \mathrm{MHz}\right.$, toluene- $d_{8}$, $\left.\mathrm{Et}_{2} \mathrm{O}, \mathrm{THF}, \mathrm{Et}_{3} \mathrm{~N}, 298 \mathrm{~K}\right): \delta 1.46$.

X-ray Crystal Structure Analyses. Pertinent data for the structure determinations are given in Table 1. Data were collected at $150 \mathrm{~K}$ on a Nonius KappaCCD diffractometer on a rotating anode (graphite-monochromated Mo K $\alpha$ radiation, $\lambda=0.71073 \AA$ ). The unit-cell parameters were checked for 
the presence of higher lattice symmetry. ${ }^{19}$ The intensity data of $\mathbf{2}$ were corrected for absorption using an algorithm based on multiple measurements of symmetry-related reflections incorporated in Platon. ${ }^{20}$ The structures were solved with direct methods using SHELXS $86^{21}$ and refined on $F^{2}$ using SHELXL-9722 (no observance criterion was applied during refinement). Hydrogen atoms were included on calculated positions riding on their carrier atoms. The methyl groups were allowed to rotate along the $\mathrm{X}-\mathrm{CH}_{3}$ bond. Non-hydrogen atoms were refined with anisotropic displacement parameters. The isotropic displacement parameters of the hydrogen atoms were linked to the value of the equivalent isotropic displace-

(19) Spek, A. L. J. Appl. Crystallogr. 1988, 21, 578.

(20) Spek, A. L. J. Appl. Crystallogr. 2003, $36,7$.

(21) Sheldrick, G. M. SHELXS86: Program for Crystal Structure Determination; University of Göttingen, Göttingen, Germany, 1986.

(22) Sheldrick, G. M. SHELXL-97: Program for Crystal Structure Refinement; University of Göttingen, Göttingen, Germany, 1997.

(23) Wilson, A. J. C., Ed. International Tables for Crystallography; Kluwer Academic: Dordrecht, The Netherlands, 1992; Vol. C. ment parameters of their carrier atoms. Neutral atom scattering factors and anomalous dispersion corrections were taken from ref 23. Validation, geometrical calculations, and illustrations were performed with PLATON. ${ }^{20}$

Acknowledgment. Prof. Dr. B. Hessen, Dr. R. A. Gossage, and Dr. P. Chase are acknowledged for their suggestions and stimulating discussion. This work was supported in part (A.L.S.) by the Council for the Chemical Sciences of The Netherlands Organization for Scientific Research (CW-NWO).

Supporting Information Available: Further details on the crystal structures of complexes $\mathbf{2}$ and $\mathbf{3 a}$, including tables of atomic coordinates, displacement parameters, bond lengths, and bond angles. This material is available free of charge via the Internet at http://pubs.acs.org.

OM049267N 